\title{
Critical Successful Factors for Innovation in Vietnamese Firms
}

\author{
Tran Hoai Nam ${ }^{1}$ D, Nham Phong Tuan ${ }^{2 *}$ (D), Nguyen Van Minh ${ }^{3}$ (D) \\ ${ }^{1,3}$ Department of Economic Information System and Electronic Commerce, Thuongmai University, Hanoi (Vietnam) \\ ${ }^{2}$ University of Economics and Business, Vietnam National University, Hanoi (Vietnam) \\ namth@,tmu.edu.vn, *Corresponding author:tuannp@,vnu.edu.vn,.minhdhtm@gmail.com
}

\section{Abstract:}

Purpose: Innovation is considered as a core element of sustainable competitive advantage in the rapidly changing environment. However, in Vietnam, researches on innovation are very rare, which are mostly general reports without underlying analyses of innovation in firms, especially determinants for innovation. Therefore, this paper focuses on analyzing critical successful factors for innovation in Vietnamese firms.

Design/methodology/approach: This study used primary data through questionnaire survey from November 2015 to February 2016. Respondents were senior managers of firms located mostly at Hanoi (Northern), Hochiminh (Southern) and Danang city (Central). The questionnaire included multi-items designed to measure factors. Each item was measured by 5 point Likert scale: 1 (strongly disagree) to 5 (strongly agree). Questionnaires were administered to 500 firms belonging to list of Vietnam Chamber of Commerce and Industry (VCCI) in these three cities with rate of $40 \%$ (Hochiminh city), 40\% (Hanoi city) and Danang (20\%). However, there were 360 returned questionnaires and valid to next analyses. Analysis methodologies of reliability, factor analysis and regression are utilized in this paper.

Findings: We developed and tested a model of determinants for Innovation in Vietnamese firms. The major contribution of this study is testing six determinants for innovation in Vietnamese companies. The results showed that awareness of innovation, innovation strategy and 
policy, organization for innovation, HR for innovation and building capabilities have positive impact on innovation.

Originality/value: This study makes a contribution for both academics and practitioners. For academics, this study provided one more empirical evidence of the determinants for innovation. Regarding practical implications, this study suggests that Vietnamese companies have to strengthen capabilities for employees through training, encourage generation of new ideas, rule breaking, and innovative behaviors by organizational members. Together, having high awareness of innovation, building rational innovation strategy and policy is essential factors that firms should possess and develop to enhance innovation performance. Although there is no confirmation for impact of finance on innovation level, firms should understand that increasing innovation investment can bring favorable condition to create innovation especially in SMEs.

Keywords: innovation, critical successful factors, Vietnam

\section{Introduction}

Businesses today face a tough reality: anticipate, respond, and react to the growing demands of the marketplace. In a fiercely competitive environment, innovation not only determines success but also governs business survival. Researching of innovation in Vietnam indicates that Vietnamese economy mostly focuses on added investment capital while knowledge and technological content are low (just over $20 \%$ ) in a long time (Nha \& Quan, 2013). Standstill of economic growth in over the recent years has been due to low labor productivity. Difficulty in attracting investment capital is main reason for Vietnam to find newly driven forces for the coming growth stage. Following emerging countries such as China, Singapore, Malaysia and Thailand, highlighting on innovation is one of basic solutions aiming at pushing up economic development currently.

Innovation is not only meaningful for nation economy as a whole, but also very important for firms. In order to increase competitiveness, firms around the world emphasize on innovation (Banbury \& Mitchell, 1995) and consider as root for creating competitive advantage (Dess \& Joseph, 2000). A recent research showed that creating value is requirement for firms in the market economy, while innovation is a tool to create value for firms (Brown, 1997). The innovation activities are not only about new product and services but also including new business methods, process and managerial models. According to Ancona and Caldwell (1987), innovation plays an important role in the long term survival of organizations. Innovation activities in organizations can help to increase problem solving process, raise productivity of 
organization by creating new idea, solution, process, and product which are adapted to the trend of society. For manufacturing firms, innovation can enhance employees' manufacturing competence and skills. Besides, it helps the firm to sharpen its competitive advantage by differentiating its products and creating value to customers. For service firms, innovation also is crucial in building competitive advantage and staying ahead of competitors. So, companies need to understand thoroughly the innovation's determinants to create and promote innovation.

Innovation is very significant for firms in the world generally and in Vietnam specifically. However, in Vietnam, researches on innovation are very rare, which are mostly general reports without underlying analyses of innovation in firms, especially determinants for innovation. Therefore, this paper is to analyze critical successful factors for innovation in Vietnamese firms.

The following section is to review related literature of critical successful factors and innovation. Research methodology is presented in section three. The fourth one is analysis results and discussion. Conclusion and implications is the last section of the paper.

\section{Literature Review and Hypothesis Development}

There have been a lot of researches of innovation in firms in the world. They are researches on definition, feature, role of innovation, relationship between innovation and business activities and performance of enterprises, conditions and factors affecting innovation in firms.

Innovation in firms is defined as using process of new knowledge of market and technology to develop new products, services, process and managerial system aiming at adapting changes of business environment and customer demand (D'Aveni, 1994). Three characteristics of innovation in firms are as follows:

- New to the market

- Usefulness

- Successful commercialize (profitability)

Innovation in firms is divided into two levels:

- Radical innovation: providing product/service which is totally new to marketplace (innovation in terms of technology, customer and market) (Danneels, 2002).

- Incremental innovation: providing product/service which is improved to marketplace. 
Schumpeter (1934) classified innovation into five basic groups, including:

- Launching new product/service or improving existing product.

- Providing new manufacturing methods

- Developing new markets

- Developing new supplement

- Organizational innovation

Apart from the intensity of innovation, the recent researches indicated two main directions of innovation that are product innovation and process innovation. The product/service innovation is related to change and adjustment of product functions (adding new functions) compared to the existing product/services in the market (Loilier \& Tellier, 1999); process innovation is associated with methods to supply services, technological process from design to distribution and commercial activities (Johnson, 2011).

The following subsection reviews only critical successful factors for innovation and then developing hypotheses as well as research framework of the paper.

\section{Critical successful factors for innovation}

Mintzberg (1982) confirmed that firms should have flexible and organic structure to make innovation better. Innovation depends much on organizing, strategic thinking, awareness of leader and development of firm culture. Administrativeness of an organization is often arestriction for innovation. Innovation is associated with team working and innovative thinking. Capabilities of employees are important factor for innovation. Risk taking and passion are two essential characteristics to implement innovation activities. Motivation and attitude of organization's members also play key role in innovation (Julien \& Jacob, 1999).

Christine, Mikel and Kevin (2002) conducted an empirical research about impact of environmental and organizational factor on innovation. The study considered effect of environmental, organizational, process, and managerial factors on incremental and radical innovation in three industries (aerospace, electronics, and telecommunication). Results showed that the environmental and organizational variables were significant factors for both kinds of the innovation. Factors affecting the incremental innovation include environmental dynamics, age and size of firm, and linkage among firms. Effects contributing to the radical innovation consist of environmental dynamics, linkages among firms, experience and transforming or restructuring from other projects or products.

According to Ferrari (2005), in order to innovate, businesses need to strongly invest in human resource and $R \& D$ activities. The market-leading enterprise always has high rate at the $R \& D$ investment. $R \& D$ contributes to inventors and new potential business ideas on the market. Inspite of the ideas and 
innovations, $R \& D$ will be ineffective if the enterprise does not have the appropriate way to implement it. It will be wasted if the new ideas and inventions are not used in this way or other ways.

Letchemenan (2006) studied the determinants to incremental and radical innovation in Malaysia industries. The research showed out the effects of internal factors on the incremental and radical innovation. These factors included organizational capacity, and demographic. Research model was approved and modified from Vincent, Bharadwaj and Challagalla (2004). The research results showed that the organizational ability and demographic implementation were important and had a positive relationship with the incremental innovation, but not the radical innovation. This also showed that very few companies in Malaysia conducted the radical innovation but the incremental innovation. The research made comments about how to manage and administer R \& D and engineering departments in the organization in order to make much better product development or innovation processes.

There have been many studies conducting research the relationship between human resources with innovation. Typically, empirical studies demonstrated human resource management affect to the development and exploitation of intellectual capital (Wright, Dunford \& Snell, 2001), knowledge creation \& product development (Collins \& Smith, 2006) and organizational learning (Snell, Youndt \& Wright, 1996). These factors in turn facilitate the innovation in business.

Based on the study on the mixed sample of enterprises in Spanish industries, Jiménez-Jiménez and Sanz-Valle (2005) demonstrated the relationship between the effective evaluation system, incentive compensation, and internal career opportunities and innovation. This study confirmed that human resource management (HRM) practices with the participation of employees in enterprises creating opportunities for the innovation. The study by Shipton, West, Dawson, Birdi and Malcolm (2006) showed that not only training but also evaluation and impact sensor affected to innovation. However, the impact of these practices can vary according to the type of innovation activity (ie: the exploitation vs exploration). The point that HRM certainly had an impact on various aspects of innovation was studied by De Leede and Looise (2005) and Jørgensen, Hyland and Kofoed (2008). Jørgensen, Becker and Matthews (2009) studied on the relationship between human resources and innovation, and confirmed that the function of HRM in corporate management system and HRM system affected the innovation capability.

Emmanuel (2008) studied the critical role of leadership in the process of organizational innovation. He argued that, in enterprises, the leaders must actively implement strategies to encourage creativity. Therefore, leadership is a catalyst and source of organizational creativity and innovation. In essence, to achieve continuous innovation for organizations, leaders must establish a favorable environment for innovation and build an organizational culture encouraging creativity and innovation. Creative organizations also depend on how leaders encourage, manage in the organization, as well as develop effective leadership structure to sustain the innovation process. Due to environmental changes in many 
areas of business today, organizations need the continuous creativity and innovation to remain competitiveness and success. This means that they must recognize and take use of the existing creativity and leadership to effectively manage innovation processes.

García-Morales, Llorens-Montes and Verdu-Jover (2006) analyzed a variety of factors that affect organizational innovation and learning, then demonstrated that organizational learning and innovation positively affect the expression of the organization. Based on previous researches, the study of GarcíaMorales et al. (2006) gave many tested theories, investigating how individualism, leadership, initiative and environment influence innovation activities. This study found out the elements of organizational innovation and learning that affected entrepreneurship and competitive advantage. Thereby it made recommendations that environment should continuously offer incentives for personal development. Management methods need to be improved and the leader needs to know how to organize and shape the model for development, thus promoting capabilities in organizations and essential strategies to do business. However, the limit of this study is that survey data based on self-reports may be bias.

The research of Lin (2006) focused on the factors affecting organizational innovation in providing logistic services. The survey was conducted with 114 companies providing logistic services in Taiwan. Factors affecting innovation include human resources and the way of organizing and implementing financial investment. Thus, it made conclusions that the human factors, organizing way and financial factors have different effects on innovation activities in providing logistic services.

Gómez-Vieites and Calvo (2011) conducted a study of factors affecting the innovation activities of Spanish businesses. The main objective of the study was to analyze the role of some factors that could influence the development of the innovation activities of large companies in Spain, exploring how these factors could help companies to achieve success by innovation and business efficiency improvement. The authors came up with a new model to analyze the relationship between the organization, technology, finance, information and cooperation elements among companies. The study used Partial Least Square (PLS) method and structural equation model to determine theoretical model, the study's data was taken from the Institute of Statistical Survey of Spain. The samples were taken from the 2224 Spanish businesses with 200 employees or more. Results showed that the resources, the cooperation and finance positively impact $\mathrm{R} \& \mathrm{D}$ activities; while $\mathrm{R} \& \mathrm{D}$, information management and technology resources had a positive impact on innovation; finally, the $\mathrm{R} \& \mathrm{D}$ activities, innovation results (product and innovation process) and business performance affect management activities of the business.

As these factors are summarized above, the authors propose a reseach model of the success factors for innovation in Vietnam including six hypotheses about the success factors for innovation in the enterprise. Compared to previous studies, this research framework is considered as more comprehensive and integrated one and thus providing one more voice for literature. 


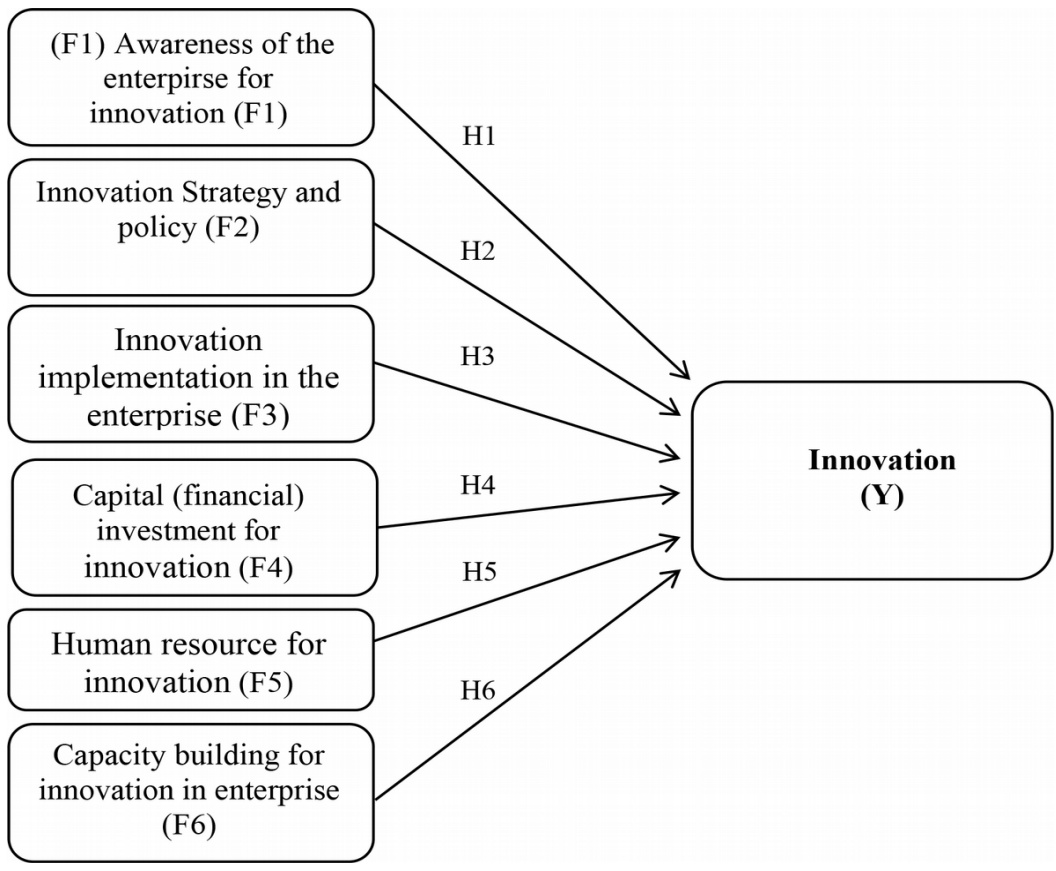

Figure 1. Research Model (authors)

Hypothesis 1 (H1): Awareness of enterprises on innovation has positive impact on innovation.

Hypothesis 2 (H2): Innovation strategy and policy have positive impact on innovation.

Hypothesis 3 (H3): Innovation implemetation in the enterprise have positive impact on innovation.

Hypothesis 4 (H4): Capital (financial) investment for innovation bas positive impact on innovation.

Hypothesis 5 (H5): Human resources for innovation has positive impact on innovation.

Hypothesis 6 (H6): Capacity building for innovation in the enterprise has positive impact on innovation.

\section{Research Methodology}

\subsection{Data and Sample}

This study used primary data through questionnaire survey from November 2015 to February 2016. Respondents were senior managers of firms located mostly at Hanoi (Northern), Hochiminh (Southern) and Danang city (Central). The questionnaire included multi-items designed to measure factors (Appendix). Each item was measured by 5 point Likert scale: 1 (strongly disagree) to 5 (strongly agree). Questionnaires were administered to 500 firms belonging to list of Vietnam Chamber of Commerce and Industry (VCCI) in these three cities with rate of 40\% (Hochiminh city), 40\% (Hanoi city) and Danang (20\%). However, there were 360 returned questionnaires and valid to next analyses. Characteristics of the survey data are described in the Table 1. 


\begin{tabular}{|c|c|c|}
\hline Data Characteristics & Frequency & $\begin{array}{l}\text { Percentage }(\%) \\
\text { of respondents }\end{array}$ \\
\hline \multicolumn{3}{|l|}{ Distributed by location } \\
\hline Hanoi & 76 & 21.1 \\
\hline Hochiminh & 119 & 33.1 \\
\hline Danang & 89 & 24.7 \\
\hline Others & 76 & 21.1 \\
\hline \multicolumn{3}{|l|}{ Main business activities } \\
\hline ICT & 52 & 14.4 \\
\hline Biological Technology & 56 & 15.6 \\
\hline Engineering-Mechanics & 63 & 17.5 \\
\hline Environmental Technology & 29 & 8.1 \\
\hline Construction Materials & 52 & 14.4 \\
\hline Services & 88 & 24.4 \\
\hline Others & 20 & 5.6 \\
\hline \multicolumn{3}{|l|}{ Legal status } \\
\hline Limited company & 161 & 44.7 \\
\hline Joint stock company & 144 & 40.0 \\
\hline Partnership & 07 & 1.9 \\
\hline Private company & 23 & 6.4 \\
\hline Others & 25 & 7.0 \\
\hline \multicolumn{3}{|l|}{ Citizenship } \\
\hline Domestic & 300 & 83.3 \\
\hline Foreign & 14 & 3.9 \\
\hline Joint venture & 46 & 12.8 \\
\hline \multicolumn{3}{|l|}{ Scope } \\
\hline Local & 129 & 35.8 \\
\hline Nation wide & 190 & 52.8 \\
\hline Southeast Asia & 25 & 6.9 \\
\hline Outside of Southeast Asia & 16 & 4.4 \\
\hline \multicolumn{3}{|l|}{ Number of employees (person) } \\
\hline Under 50 & 128 & 35.5 \\
\hline $51-100$ & 91 & 25.3 \\
\hline $101-300$ & 141 & 39.2 \\
\hline Over 300 & 0 & \\
\hline \multicolumn{3}{|l|}{ Revenue (VNĐ) } \\
\hline Under 1 billion & 75 & 20.8 \\
\hline 1 bil - 10 bil & 110 & 30.6 \\
\hline 10 bil - 50 bil & 71 & 19.7 \\
\hline 50 bil - 100 bil & 26 & 21.7 \\
\hline Over 100 bil & 78 & 7.2 \\
\hline Total (respondents) & 360 & 100 \\
\hline
\end{tabular}

Table 1. Characteristics of the survey data $(\mathrm{N}=360)$ (summarized by authors from survey) 


\subsection{Analytical Methodology}

Authors used SPSS software to analyze collected data through 3 steps. Firstly, Cronbach's Alpha coefficients are used for testing the reliability of scales, the test determines the internal consistency or average correlation of items in a survey instrument to gauge its reliability. When it comes to reliability test, the data are considered to be reliable if Cronbach's Alpha coefficients are greater than 0.7.

Secondly, Exploratory Factor Analysis (EFA) is used to uncover the underlying structure of a relatively large set of variables. EFA is a technique within factor analysis whose overarching goal is to identify the underlying relationships between measured variables. The authors perform this analysis because there is no priori hypothesis about factors or patterns of measured variables. In this test, all items which have Factor Loading greater than 0.5 will be kept.

Finally, we finish analysis process by performing Linear Regression Analysis to test the validity of six hypotheses. The main purpose of regression analysis is used to describe the relationship among variables and predict the value of one variable given the values of the others.

\section{Results and Discussion}

\subsection{Reliability Test}

Table 2 shows results of the reliability test. The result is favorable because all Cronbach Alpha coefficients of factors including Awareness of innovation (0.946), Strategy and policies for innovation (0.956), Organization for innovation (0.771), Financing for innovation (0.877), HR for innovation (0.884), Capacity building for innovation (0.882), and Innovation are much greater than 0.7 which is the standard acceptable value of factor reliability test. 


\begin{tabular}{|c|c|c|c|}
\hline Measures & $\begin{array}{l}\text { Corrected Item-Total } \\
\text { Correlation }\end{array}$ & $\begin{array}{l}\text { Cronbach's Alpha if } \\
\text { Item Deleted }\end{array}$ & Cronbach's Alpha \\
\hline \multicolumn{4}{|c|}{ Awareness of Innovation } \\
\hline F11 & .906 & .906 & \multirow{3}{*}{0.946} \\
\hline F12 & .894 & .915 & \\
\hline F13 & .862 & .939 & \\
\hline \multicolumn{4}{|c|}{ Strategy and Policies for Innovation } \\
\hline $\mathrm{F} 21$ & .906 & .939 & \multirow{3}{*}{0.956} \\
\hline F22 & .936 & .914 & \\
\hline F23 & .885 & .953 & \\
\hline \multicolumn{4}{|c|}{ Organization for innovation } \\
\hline F31 & .663 & .665 & \multirow{4}{*}{0.771} \\
\hline F32 & .502 & .753 & \\
\hline F33 & .551 & .730 & \\
\hline F34 & .587 & .709 & \\
\hline \multicolumn{4}{|c|}{ Financing for innovation } \\
\hline F41 & .770 & .818 & \multirow{3}{*}{0.877} \\
\hline $\mathrm{F} 42$ & .787 & .804 & \\
\hline $\mathrm{F} 43$ & .730 & .855 & \\
\hline \multicolumn{4}{|l|}{ HR for innovation } \\
\hline F51 & .822 & .791 & \multirow{3}{*}{0.884} \\
\hline F52 & .780 & .829 & \\
\hline F53 & .721 & .882 & \\
\hline \multicolumn{4}{|c|}{ Capacity building for innovation } \\
\hline F61 & .760 & .847 & \multirow{5}{*}{0.882} \\
\hline F62 & .779 & .843 & \\
\hline F63 & .730 & .854 & \\
\hline F64 & .666 & .869 & \\
\hline F65 & .655 & .871 & \\
\hline \multicolumn{4}{|l|}{ Innovation } \\
\hline $\mathrm{Y} 1$ & .805 & .855 & 0.900 \\
\hline
\end{tabular}

Table 2. Reliability statistics 


\subsection{Exploratory Factor Analysis}

EFA is performed orderly for independent variables and dependent variable based on our model. Firstly, all measured items of independent factors are put in EFA, the results are illustrated in Table 3.

\begin{tabular}{|c|c|c|c|c|c|c|}
\hline \multicolumn{7}{|c|}{ Rotated Component Matrix } \\
\hline & \multicolumn{6}{|c|}{ Component } \\
\hline & 1 & 2 & 3 & 4 & 5 & 6 \\
\hline F65 & .844 & & & & & \\
\hline F64 & .794 & & & & & \\
\hline F62 & .713 & & & & & \\
\hline F61 & .708 & & & & & \\
\hline F63 & .649 & & & & & \\
\hline F51 & & .850 & & & & \\
\hline F52 & & .824 & & & & \\
\hline F53 & & .813 & & & & \\
\hline F13 & & & .912 & & & \\
\hline $\mathrm{F} 12$ & & & .912 & & & \\
\hline F11 & & & .911 & & & \\
\hline F21 & & & & .856 & & \\
\hline $\mathrm{F} 22$ & & & & .830 & & \\
\hline F23 & & & & .826 & & \\
\hline $\mathrm{F} 42$ & & & & & .857 & \\
\hline $\mathrm{F} 43$ & & & & & .852 & \\
\hline F41 & & & & & .843 & \\
\hline F32 & & & & & & .761 \\
\hline F33 & & & & & & .744 \\
\hline F31 & & & & & & .724 \\
\hline F34 & & & & & & .665 \\
\hline
\end{tabular}

Table 3. Exploratory Factor Analysis for independent variables

From Table 3 we can keep all items because their factor loadings are greater than 0.5. After implementing the EFA of independent variables, 21 variables can be shortened into 6 factors.

- Awareness of Innovation: identified by F11, F12, F13.

- Strategy and Policies for Innovation: identified by F21, F22, F23.

- Organization for innovation: identified by F31, F32, F33, and F34.

- Financing for innovation: identified by F41, F42, and F43. 
- HR for innovation: identified by F51, F52, F53.

- Capacity building for innovation: identified by F61, F62, F63, F64, F65.

Three last items are put into EFA for analyzing underlying factors of dependent variable. Table 4 indicates favorable result because only 1 factor is extracted. We conclude that "Innovation" factor is identified by three items $\mathrm{Y} 1, \mathrm{Y} 2$ and $\mathrm{Y} 3$.

\begin{tabular}{|c|c|}
\hline \multirow{2}{*}{} & \multicolumn{2}{|c|}{ Component Matrix } \\
\cline { 2 - 3 } & \multicolumn{2}{|c|}{ Component } \\
\hline Y2 & \multicolumn{1}{|c|}{} \\
\hline Y1 & .923 \\
\hline Y3 & .914 \\
\hline
\end{tabular}

Table 4. Exploratory Factor Analysis for dependent factor

\subsection{Regression Analysis Results}

Table 5 shows regression results, in which six independent variables were regressed against one dependent variable. Correspondingly, all hypotheses were estimated by looking at P-value of each variable. This paper takes three significant level of $1 \%, 5 \%$ and $10 \%$, which means hypotheses are supported if their $P$ value is at that level.

\begin{tabular}{|c|c|c|c|c|c|c|c|}
\hline Hypothesis & $\begin{array}{l}\text { Relationship between } 6 \\
\text { independent variables and } \\
\text { "Innovation" }\end{array}$ & F-statistic & $\begin{array}{l}\text { Adjusted } \\
\qquad \mathbf{R}^{2}\end{array}$ & VIF & $\begin{array}{l}\text { Standardized } \\
\text { Coefficient }\end{array}$ & $\begin{array}{l}\text { Critical } \\
\text { ratio }\end{array}$ & p-value \\
\hline $\mathrm{H} 1$ & Awareness of Innovation & \multirow{6}{*}{26.184} & \multirow{6}{*}{0.296} & 1.304 & .119 & 2.346 & $0.020^{* *}$ \\
\hline $\mathrm{H} 2$ & $\begin{array}{l}\text { Strategy and Policies for } \\
\text { Innovation }\end{array}$ & & & 1.987 & .120 & 1.916 & $.056^{*}$ \\
\hline $\mathrm{H} 3$ & Organization for innovation & & & 1.492 & .094 & 1.747 & $.082^{*}$ \\
\hline $\mathrm{H} 4$ & Financing for innovation & & & 1.484 & .011 & .197 & .844 \\
\hline H5 & HR for innovation & & & 1.597 & .111 & 1.975 & $.049^{* *}$ \\
\hline H6 & $\begin{array}{l}\text { Capacity building for } \\
\text { innovation }\end{array}$ & & & 1.817 & .317 & 5.313 & $.000^{* * * *}$ \\
\hline
\end{tabular}

Note: ${ }^{* * *}$ : significant at $1 \% ;{ }^{* *}$ : significant at $5 \% ;{ }^{*}$ : significant at $1 \%$

Table 5. Regression Results

From Table 5, we can see that six variables jointly have significant impact on "Innovation" because the F-statistic is very high (26.184). Besides, adjusted $\mathrm{R}^{2}$ indicates that six independent variables can explain 
$29.6 \%$ of the variation of dependent variable. There is no multicollinearity phenomenon because all of VIF statistics are pretty smaller than 4 (rule of thumb).

\section{Hypothesis 1}

Hypothesis 1 states that Awareness of Innovation has a positive impact on Innovation in organizations. This hypothesis is supported because p-value is 0.020 that is less than 0.05 . This result is consistent with innovation process that has been studied in the past, typically in studies of Rogers (1995) and Zaltman, Duncan and Holbek (1973). For a successful innovation, the process includes awareness of innovation, attitude formation, evaluation, decision to adopt, trial implementation and sustained implementation. Another research of Liao, Kickul and Ma (2009) also argued that firms' awareness of innovation can foster the firm to create innovative products and services as well as offer innovative operating practices.

\section{Hypothesis 2}

Hypothesis 2 assumes that the Strategy and Policies for Innovation positively influence Innovation in the firms. The relationship is significant because $\mathrm{p}$-value is less than $0.1(\mathrm{p}=0.056)$. There is a support for Hypothesis 2 with 10\% of significance. This result is consistent with findings of Kalay and Lynn (2015) determining the positive impact of strategy for innovation on innovation success in a company. It is really important for a company to plan innovative strategy as well as establish policy for innovation such as encouraging innovative ideas and diffusing them in the company. Same as research of Balachandra and Friar (1997), strategy and social capital are critical determinants of innovation. Strategy and policy for innovation in a firm is a guide that makes firms think about why they innovate before attempting to make an innovation. Lendel and Varmus (2011) have shown that innovation strategy can enhance innovative potential of the firm. Similarly, O'Regan, Ghobadian and Gallear (2005) also pointed out that firms owning an innovation strategy always are more successful in innovation than those do not have innovation strategy.

\section{Hypothesis 3}

This hypothesis supposes that the Organization for innovation can affect positively to Innovation in organizations. The results in Table 5 shows that this hypothesis is validated with $10 \%$ significance because $\mathrm{p}$-value is less than $0.1(\mathrm{p}$-value $=0.082)$. This finding has been pointed out by some previous researches. In the study of Smith, Busi, Ball and Meer (2008), organizational structure as well as organization for 
innovation strongly affects innovation process in a positive way. Based on research of Mumford, Whetzel and Palmon (1997), well-established work teams for innovation which allow diversity and individual talents can foster level of innovation in an organization. Martin and Terblanche (2003) in study of organizational culture have pointed lots of factors that related to organization for innovation. So, for higher level of innovation in a company, there is a need of reasonable organizational structure, organizing process for innovation.

\section{Hypothesis 4}

Hypothesis 4 was argued to propose a positive relationship between Financing for innovation and Innovation activities in the company. However, the result does not support this hypothesis because the pvalue is much larger than $0.05(\mathrm{p}=0.884)$. This finding is controversial and conflict with some previous findings. In report of Aubert (2015), finance is an essential factor to promote innovation activities for low technology SMEs and micro enterprises. Mahendra, Zuhdi and Muyanto (2015) also stated that access to finance is an important factor of innovation level in organization. However, financing for innovation is a more difficult investment because innovative projects always have higher risks than others. Investors or managers therefore are worry more about the investment put in innovation. Moreover, raising money from external sources creates information asymmetry problems between firms and external investors because it is difficult to monitor innovation. Thus, it is rational to say that financing for innovation cannot predict level of innovation in a company, unless that company has developed specialization in financing innovation. In addition, it should be noted that level of financing for innovation depends on size of firms, whereas level of innovation in a small company may be much higher than a large organization. In a research of Biosca (2009), they showed that merely increasing availability of funding for innovation is not sufficient. As a matter of fact, in Vietnam's context, how to let people involve in innovation process is much more important.

\section{Hypothesis 5}

In Hypothesis 5, HR for innovation is supposed to have a positive effect on Innovation activities of organization. The result is favorable because the p-value is 0.049 that is less than 0.05 and critical value is 1.975. In general, the hypothesis is supported with the coefficient of relationship is 0.111 . The result is supported by many previous studies about HR and innovation. Klein and Sorra (1996) found that firms have to focus on HR for innovation, ensuring employee's skills, providing incentives to foster innovative activities. Lau and Ngo (2004) said that a HR system is really important for an oriented innovation 
organization. The HR system has to include: training-focus, performance-based reward and team development for higher level of innovation. It is important to focus on developing an innovative and entrepreneurial culture by managing the HR functions properly. Innovation can only be established if employees have the possibility to be innovative. Management should give employees more space, facilitation, excitement and challenges to come up with distinctive concepts. Positive impact of HR on innovation also was confirmed by research of Allani, Arcand and Bayad (2003), they considered HR is a key factor for company's competitiveness and critical capacity for innovation. Other studies of Karlsson (2013), Arulrajah (2014) and Ghamdi and Razek (2015) explored the relationship between organizational HRM practices and innovation, and the conclusion was that HRM practices are important to foster organizational innovation.

\section{Hypothesis 6}

Last hypothesis in this paper states that Capacity building for innovation has positive impact on Innovation in organizations. We can see that the $\mathrm{p}$-value is pretty small $(0.000<0.05)$, so that the relationship is strongly supported. The coefficient of relationship between Capacity building for innovation and Innovation is 0.317 . The result is consistent with research of Lau \& Ngo (2004), training focused and building capabilities for employees have strong link with innovation performance. Lawson and Samson (2011) studied about how to develop capabilities for innovation has concluded that building capabilities which have seven aspects will help firms in achieving sustainable innovation outcomes as the engine of their business performance. Snyder (2013) stated that capabilities in an organization are necessary requirement for innovation adoption decision. Furthermore, Alegre and Chiva (2008) showed a positive link between requirement for organizational learning capabilities and innovation performance.

The following table (Table 6) shows summary of hypothesis estimation of this research. Overall, out of six hypotheses, five hypotheses (H1, H2, H3, H5, H6) are supported on the basic of three significant level of $P$ value. 


\begin{tabular}{|l|c|}
\hline \multicolumn{1}{|c|}{ Hypotheses } & $\begin{array}{c}\text { Estimated } \\
\text { results }\end{array}$ \\
\hline Hypothesis 1 (H1): Awareness of enterprises on innovation has positive impact on innovation. & Supported \\
\hline Hypothesis 2 (H2): Innovation strategy and policy have positive impact on innovation. & Supported \\
\hline Hypothesis 3 (H3): Innovation implemetation in the enterprise have positive impact on innovation. & Supported \\
\hline Hypothesis 4 (H4): Capital (financial) investment for innovation has positive impact on innovation. & Rejected \\
\hline Hypothesis 5 (H5): Human resources for innovation has positive impact on innovation. & Supported \\
\hline Hypothesis 6 (H6): Capacity building for innovation in the enterprise has positive impact on innovation. & Supported \\
\hline
\end{tabular}

Table 6. Summary of hypothesis estimation

\section{Conclusion and Implication}

In this study, we developed and tested a model of determinants for Innovation in Vietnamese firms. The major contribution of this study is testing six determinants for innovation in Vietnamese companies. The results showed that awareness of innovation, innovation strategy and policy, organization for innovation, HR for innovation and building capabilities have positive impact on innovation. From the results, this study makes a contribution for both academics and practitioners. For academics, this study provided one more empirical evidence of the determinants for innovation.

Regarding practical implications, firstly, this research proposes that awareness of innovation can positively influences innovation activities in Vietnamese firms. So, awareness of innovation can be considered as first stage of innovation strategy in the firm. If there is no awareness in the firm, innovation cannot be performed. To increase innovation awareness in Vietnamese organizations, it is important to create campaign or showcase about innovation for raising innovation awareness purpose. Furthermore, leaders and managers in the company should pay more attention to train the employees about the necessity of innovation, encourage them to explore and contribute new ideas for company. Increasing innovative awareness of individuals in company can establish an innovative environment that promotes innovation in that company.

Secondly, the result in this study has shown that strategies and policies for innovation is one of drivers of innovation in organization. A firm is considered is more innovative if it has suitable innovation strategy and policy. So, to be innovative and dominant over other competitors, a company should know how to manage its resource to create an open, adaptive innovation strategy to reach desirable future state of the company.

Thirdly, organization for innovation also is a critical factor can affect innovation performance within a firm. The study shows positive influence of organization for innovation on innovation, that means how a company organizes, implement innovation activities can affect innovation success. The company should 
empower employees to encourage innovative ideas, motivating leaders and employees to involve in innovation process, as well as collaborating with external partners for potential innovative projects.

Fourthly, this research points out that more human resource company uses for innovation activities, there will be higher level of innovation. So, companies which desire a higher level of innovation should concentrate on how to increase number of people involved in innovation process, especially highexpertise people. Moreover, when it comes to a person who has high capability of innovation, there should be a reasonable motivation as well as compensation for that person such as reward or promotion.

Finally, the result suggests that firms have higher building capabilities activities within organization will more likely to have high level of innovation. As a part of HR system to increase innovation, firms need to provide necessary skills for employees through focus on training. It is essential for diffusing the knowledge, skills for employees as well as leaders, managers in the company. If companies do not have sources of innovation knowledge and skills, they can invest more money in training activities from external sources. Building capabilities for innovation activities should be implemented frequently with diverse training content.

There are some limitations in this study that can be improved by future researches. Firstly, the sample is taken in Vietnam country and mostly from small and medium enterprises so as a result, the findings may be limited to this sample. It would be more interesting if future study can expand the sample in a larger context, take data from more firms as well as more employees in each firm. Secondly, innovation is a large area to study about, this study only found out some internal factors which can affect innovation in an organization. Future research can expand the model to test the impact of some external factors on innovation of Vietnamese firms. Finally, the questionnaire contains some broad questions so that Likert 5-point scale might not obtain full information on the factors studied. Future researches could attempt to obtain data more specifically from multiple sources.

\section{Acknowledgement}

This research is funded by Vietnam National Foundation for Science and Technology Development (NAFOSTED) under grant number 502.02-2016.03 


\section{References}

Alegre, J., \& Chiva, R. (2008). Assessing the impact of organizational learning capability on product innovation performance: An empirical test. Technovation, 28(6), 315-326.

https://doi.org/10.1016/j.technovation.2007.09.003

Allani, N., Arcand, M., \& Bayad, M. (2003). Impact of Strategic Human Resources Management on Innovation. 12th International Conference on Management of Technology: LAMOT. 13-15.

Ancona, D.G., \& Caldwell, D.F. (1987). Management issues facing new-product teams in high technology companies. In Advances in Industrial and Labor Relations. 4, 191-221. Greenwich: JAI Press.

Arulrajah, A. (2014). Human resource management practices and innovation: a review of literature. 11th International Conference on Business Management.

Aubert, J.E. (2015). Promoting innovation in developing countries: A conceptual framework. World Bank Institute. https://doi.org/10.1596/1813-9450-3554

Balachandra, R., \& Friar, J. (1997). Factors for success in R\&D projects and new product innovation: a contextual framework. IEEE Transactions on Engineering Management, 44(3), 276-287.

https://doi.org/10.1109/17.618169

Banbury, C.M., \& Mitchell, W. (1995). The Effect of Introducing Important Incremental Innovations on Market Share and Business Survival. Strategic Management Journal, 16(Special Issue), 161-182. https://doi.org/10.1002/smj.4250160922

Biosca, A.B. (2009). Access to Finance for Innovation: Rationales and Risks of Public Intervention. The innovation policy platform.

Brown, D. (1997). Innovation Management Tools: A Review of Selected Methodologies. EIMS Publication, 30. Luxembourg: European Communities.

Christine, O., Mikel, L., \& Kevin, M. (2002). The regional innovation paradox: Innovation policy and industrial policy. Journal of technological Transfer, 27, 97-110. https://doi.org/10.1023/A:1013104805703

Collins, C.J., \& Smith, K.G. (2006). Knowledge Exchange and Combination: The Role of Human Resource Practices in the Performance of HighTechnology Firms. Academy of Management Journal, 49, 544-560. https://doi.org/10.5465/AMJ.2006.21794671

D’Aveni, R.A. (1994), Hypercompetition: Managing the Dynamics of Strategic Manoeuvring. New York: The Free Press. 
Danneels, D. (2002). The Dynamics of Product Innovation and Firm Competences. Strategic Management Journal, 23, 1095-1121. https://doi.org/10.1002/smj.275

De Leede, J., \& Looise, J.K. (2005). Innovation and HRM: Towards an integrated framework. Creativity and Innovation Management, 14 (2), 108-117. https://doi.org/10.1111/j.1467-8691.2005.00331.x

Dess, G.G., \& Joseph, C.P. (2000). Changing roles: Leadership in the 21st Century. Organizational Dynamics: Winter 2000. 18-34. https://doi.org/10.1016/S0090-2616(00)88447-8

Emmanuel, A. (2008), Creativity and Innovation: The Leadership Dynamics. Journal of Strategic Leadership, 1(1), 39-45.

Ferrari, M. (2005). Le management des equips de R\&D entre organisation et contrat d'incitation: l'essaimage strategique. Revue de gestion des ressources humaines, 30(1), 124-140. http://archive-ouverte.unige.ch/unige:41650

García-Morales, V.J., LLorens-Montes, F.J., \& Verdu-Jover, A.J. (2006). Organisational learning categories: their influence on organisational performance. International Journal of Innovation and Learning, 3(5), 518536. https://doi.org/10.1504/IJIL.2006.010487

Ghamdi M.A., \& Razek R.A. (2015). The impact of human resource management on technological innovation in jubail primary industrial sector, Kingdom of Saudi Arabia. International Journal of Business and Management, 3(2). https://doi.org/10.20472/BM.2015.3.2.001

Gómez-Vieites, A., \& Calvo, J.L. (2011). A Study on the Factors That Influence Innovation Activities of Spanish Big Firms. Technology and Investment, 2, 8-19. https://doi.org/10.4236/ti.2011.21002

Jiménez-Jiménez, D., \& Sanz-Valle, R. (2005). Innovation and human resource fit: An empirical study. International Journal of Manpower, 36(4), 364-398. https://doi.org/10.1108/01437720510609555

Johnson, W.S. (2011). Strategique. Pearson Education France.

Jørgensen, F., Hyland, P., \& Kofoed, L. (2008). Examining the role of Human Resource Management in Continuous Improvement. International Journal of Technology Management, 42(1/2), 127-142. https://doi.org/10.1504/IJTM.2008.018064

Jørgensen, F., Becker, K., \& Matthews, J. (2009). Human Resource Management and Innovation: What are Knowledge-Intensive Firms Doing? Published in the proceedings for the 10th international CINET conference. Enhancing the Innovation Environment. Brisbane, Australia.

Julien, P.-A., \& Jacob, R., (1999), La transformation du rôle de l'entrepreneur et l'économie du savoir, Revue internationale de gestion, 24(3), 43-50. 
Kalay, F., \& Lynn, G.S. (2015). The impact of strategic innovation management practices on firm innovation performance. Research Journal of Business and Management. 2(3), 412-429. https://doi.org/10.17261/Pressacademia.2015312989

Karlsson, J. (2013). The role of HRM in innovation processes: Nurturing or constraining creativity. University of Gothenburg. https://gupea.ub.gu.se/bitstream/2077/33647/1/gupea 207733647 1.pdf (Accessed: June 2016).

Klein, K.J., \& Sorra, J.S. (1996). The challenge of innovation implementation. Academy of Management, 21, 1055-1080. https://doi.org/10.5465/AMR.1996.9704071863

Lau, C.M., \& Ngo, H.Y. (2004). The HR system, organizational culture, and product innovation. International Business Review. 13(6), 685-703. https://doi.org/10.1016/j.ibusrev.2004.08.001

Lawson, B., \& Samson, D.A. (2001). Developing innovation capability in organisations: A dynamic capabilities approach. International Journal of Innovation Management, 5(3), 377-400. https://doi.org/10.1142/S1363919601000427

Lendel, V., \& Varmus, M. (2011). Creation and implementation of the innovation strategy in the enterprise. Economics and Management, 16, 819-826.

Letchemenan, G. (2006). Organization Determinants of Incremental and Radical Innovations in Industries Operating In Malaysia. Universiti Sains Malaysia. http://eprints.usm.mv/25566/1/Organization Determinants of Incremental and Radical Innovations in Industries Op erating.pdf

Liao, J., Kickul, J.R., \& Ma, H. (2009). Organizational Dynamic Capability and Innovation: An Empirical Examination of Internet Firms. Journal of Small Business Management, 47(3), 263-286. https://doi.org/10.1111/j.1540-627X.2009.00271.x

Lin, C.-Y. (2006). Determinants of organizational innovation for logistics service providers in Taiwans. Journal of Statistics \& Management Systems, 9(3), 613-631. https://doi.org/10.1080/09720510.2006.10701226

Loilier, T., \& Tellier, A.(1999). Gestion de linnovation, Management et Société. Les essentiels de la gestion. Editions EMS.

Mahendra E., Zuhdi U., \& Muyanto Z. (2015). Determinants of Firm Innovation in Indonesia: The Role of Institutions and Access to Finance. Economics and Finance in Indonesia, 61(3), 149-179.

Martin, E.C., \& Terblanche, F. (2003). Building organisational culture that stimulates creativity and innovation. European Journal of Innovation Management, 6, 64-74. https://doi.org/10.1108/14601060310456337

Mintzberg, H. (1982). Structure et Dynamiques des Organisations. Paris: Editions d'organisation. 
Mumford, M.D., Whetzel, D.L., \& Palmon, R.R. (1997). Thinking Creatively at Work: Organization Influences on Creative Problem Solving. The Journal of Creative Behavior, 31(1), 7-17. https://doi.org/10.1002/j.2162-6057.1997.tb00777.x

Nha, P.X., Quan, L. (2013). Đổi mới sáng tạo của doanh nghiệp Việt Nam. Tạp chí Khoa học ĐHQGHN. Kinh tế và Kinh doanh, 29(4), 1-11.

O'Regan, N., Ghobadian, A., \& Gallear, G. (2005). In search of the drivers of high growth in manufacturing SMEs. Technovation, 26(1), 30-41. https://doi.org/10.1016/j.technovation.2005.05.004

Rogers, E.M., (1995). Diffusion of innovations. 4th ed. New York: The Free Press.

Schumpeter, J.A. (1934). The Theory of Economic Development. Harvard University Press.

Shipton, H., West, M.A., Dawson, J., Birdi, K., \& Malcolm, P. (2006). HRM as a predictor of innovation. Human Resource Management Journal, 16 (1), 3-27. https://doi.org/10.1111/j.1748-8583.2006.00002.x

Smith, M., Busi, M., Ball, P., \& Meer, R.V.D. (2008). Factors influencing an organisation's ability to manage innovation: A structured literature review and conceptual model. International Journal of Innovation Management, 12(4), 655-676. https://doi.org/10.1142/\$1363919608002138

Snell, S.A., Youndt, M.A., \& Wright, P.M. (1996), Establishing a framework for research in Strategic Human Resource Management: Merging Resource-Based Theory and Organizational Learning. In Ferris, G.R., \& Rowland, K.M. (Eds.). Research in Personnel and Human Resource Management, 14, 61-90. Greenwich, CT: JAI Press.

Snyder, K. (2013). The Role of Capabilities in Innovation Adoption Decisions. Dissertations. 707. http://scholarworks.umass.edu/open access dissertations/707/

Vincent, L.H., Bharadwaj, S.G., \& Challagalla, G.N. (2004). Does Innovation Mediate Firm Performance?: A Meta-Analysis of Determinants and Consequences of Organizational Innovation”. http://smartech.gatech.edu/handle/1853/10731

Wright, P., Dunford, B., \& Snell, S. (2001). Human Resources and the Resource Based View of the Firm. Journal of Management, 27, 701-721. https://doi.org/10.1177/014920630102700607

Zaltman, G., Duncan, R., \& Holbek, J. (1973). Innovations and organizations. New York: Wiley. 


\section{Appendix: Questionnaires}

Innovation of firm $(\mathrm{Y})$

Y1 - level of providing totally new product/service to market

Y2 - level of providing improved product/service to market

Y3 - level of penetrating into new market (product/service in new geographical area, new customer segmentation).

Awareness of firm for innovation (F1)

F11 - Awareness of leader for innovation

F12 - Awareness of employees of firm for innovation

F13 - Employees recognize content and plan of innovation

Strategy and policy for innovation (F2)

F21 - level of sharing strategies, policies for innovation in the firm

F22 - level of implementing strategies, policies for innovation

F23 - level of expressing opinions for innovation (issuing and conducting ideas shared and respected, sharing and receiving new knowledge...)

Organization for innovation (F3)

F31 - making effort for implementing invent, ideas

F32 - self- implementing capability for invent, ideas

F33 - successful level of cooperating with external partners to implement innovative projects.

F34 - capability to handle possible issues when implementing innovation in firm 
Capital (financing) investment for innovation (F4)

F41 - actively financing for innovation activities

F42 - investment rate for innovation activities in comparison with total investment of firm

F43 - satisfied level with investment outcome for innovation activities

Human resources for innovation (F5)

F51 - rate of number of employees involving innovation activities over total number of employees in firm.

F52 - innovative capability of employees

F53 - employees with innovative capability are prioritized and compensated (recruitment, training, incentives, promotion, assignment, keeping).

Building innovative capability in firm (F6)

F61 - often implementing activities to help improve innovative capability for employees

F62 - training need for improving innovative capability

F63 - diversity of topic and training content to improve innovative capability

F64 - firm satisfies achievement from training activities of improving innovative capability

F65 - investment budget for training activities of improving innovative capability (compared to total investment of firms)

Journal of Industrial Engineering and Management, 2017 (www.jiem.org)

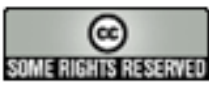

Article's contents are provided on an Attribution-Non Commercial 3.0 Creative commons license. Readers are allowed to copy, distribute and communicate article's contents, provided the author's and Journal of Industrial Engineering and Management's names are included. It must not be used for commercial purposes. To see the complete license contents, please visit http://creativecommons.org/licenses/by-nc/3.0/. 